\title{
14
}

\section{Indigenous peoples embedded in neoliberal governance: Has the Māori Party achieved its social policy goals in New Zealand?}

\author{
Louise Humpage
}

\section{Introduction}

The re-election of conservative governments in many countries in the 2010s suggests that neoliberalism has become normalised and neoliberal values represent 'a common sense of the times' (Peck \& Tickell 2002: 381). Yet, indigenous protest movements and political agency exemplify the kind of ongoing 'resistances, refusals, and blockages' that Clarke (2004: 44) believes hinder the smooth running of global neoliberalisation. Despite considerable policy coherence under neoliberal governance, the nuanced, dynamic concept of neoliberalisation highlights that differing forms of neoliberalism exist across temporal phases and geographical spaces (Peck \& Tickell 2002). As other chapters in this volume illustrate, neoliberalism has inhibited indigenous wellbeing and rights and provided important opportunities for indigenous peoples in varied ways across the world.

In New Zealand, for instance, public disgruntlement with neoliberal policies was one factor behind the adoption of a mixed-member proportional (MMP) representation system, which, in turn, saw an 
increase in the number of electorate seats made available to indigenous Māori in the New Zealand Parliament. Labour MP Tariana Turia caused a by-election in one of these seats in 2004 when refusing to vote for her own government's legislation placing the foreshore and seabed into public ownership, thus denying Māori tribes an opportunity to seek judicial recognition of their continued ownership of this important resource. Her new Māori Party went on to win four Māori electorate seats in the 2008 election. Although the conservative National Party held sufficient general electorates under MMP to govern alone in 2008, it negotiated supply and confidence agreements with smaller parties. This included the Māori Party, challenging an historical alliance between Māori electorates and the Labour Party (Bargh 2015). The relationship continued until the 2017 election, when a Labour-New Zealand First Government came to power (Election Aotearoa 2017).

The Māori Party combines 'a drive towards rangatiratanga [selfdetermination], and an attempt to address the socio-economic needs of Māori' (Smith 2010: 215, emphasis added). Relatively poor levels of health, education, housing and income/wealth among Māori compared to non-Māori New Zealanders (Marriott \& Sim 2014) explain why social policy is central to the Mãori Party's political platform. Consequently, this chapter focuses on analysis of two key social policy initiativesWhānau Ora and the Ministerial Committee on Poverty-resulting from Māori Party-National Party relationship accords. At the time of writing, both continued under the new government. Yet some critics claim the Māori Party's relationship with National favoured tribal elites at the expense of the poor (Sykes 2010, Harawira 2011, see also Bargh, Chapter 16, and McCormack, Chapter 15, this volume). Others view Māori Party support or silence on neoliberal/neoconservative agendassuch as the weakening of environmental regulations in return for greater consultation/representation rights for iwi-as evidence the Māori Party 'sold out' to neoliberalism (Sachdeva 2015, see McCormack this volume, Chapter 15). This chapter considers how each policy challenges and extends a neoliberal agenda, arguing that the Mãori Party began to achieve its goals in social policy but political constraints inhibited this new opportunity for an indigenous party to make a significant and lasting difference in the social policy arena and, potentially, to hinder the smooth running of neoliberalism. 


\section{New Zealand's unique political context}

Specific indigenous representation in parliament has existed since Māori electorate seats were established in 1867, providing unique opportunities for Māori to shape New Zealand politics. Forming part of a ruling government offered the Māori Party unprecedented leverage compared to earlier dedicated Māori political parties (Bargh 2015). Supply and confidence agreements require the Māori Party to support the National Party's position in all matters subject to confidence and supply votes in the House of Representatives, as well as on any budgetary or procedural votes needed to pass Bills in parliament. But, in return, the Māori Party gained:

- the right to be consulted on major legislative, budget and policy issues to which the Mãori Party is likely to be sensitive

- several key ministerial or associate ministerial positions outside of Cabinet for the Māori Party co-leaders

- progress on Māori Party policies, including the replacement of the Foreshore and Seabed Act 2004, which was the catalyst for the establishment of the party; an agreement there would be no attempt to remove nor entrench the Māori electorate seats; a constitutional review; the signing of the United Nations Declaration on the Rights of Indigenous Peoples (UNDRIP); and funds to improve Māori electoral participation (NP \& MP 2008, 2011, 2014, English 2016).

Although these policy gains would likely have remained unfulfilled without the Māori Party's influence, critics (Sykes 2010, Harawira 2011) rightly argue that the policy gains were limited and did not fundamentally change Māori lives. The Māori Party claims that it voted against National more than it voted with it. But there are also significant overlaps between National's neoliberal agenda and the economic interests of tribes and Māori businesses with significant assets (see Bargh this volume, Chapter 16), as well as articulated beliefs that the welfare system is part of the 'problem' for Māori, requiring both greater individual and familial responsibility and decentralised models of funding (Turia 2006).

Nonetheless, some members of National's core constituency actively resist recognition of either indigenous rights or the rights associated with the 1840 Treaty of Waitangi, New Zealand's 'founding document'. The National Party itself tends to acknowledge the Treaty's Article 2, which articulates the right to self-determination when considering resource claim settlements, but not in social policy where it prioritises Article 3's 
promise of equal citizenship rights (Humpage 2005, see O'Sullivan this volume, Chapter 13). We might therefore expect many National voters to feel uncomfortable about their party's formal relationship with the Māori Party, whose kaupapa (agenda or philosophy) is based on nine key principles summarised in the left-hand column of Table 14.1. Referring to this kaupapa, Turia (cited by Leahy 2015: 357) has highlighted: 'The Māori Party does not intend to operate like any other political party. The tikanga Māori [Māori custom] nature of the party is an essential part of the justification for its existence'.

Scholars (Peck \& Tickell 2002, Clarke 2004, Humpage 2015) caution against homogenising the 'actually existing' neoliberalism that has emerged in differing geographical and temporal contexts, while O'Sullivan in this volume notes how it is easy to overstate the tensions between indigenous cultural and economic aspirations. Nonetheless, brevity requires Table 14.1's rather simplistic summary of relevant key principles associated with both the Māori Party and neoliberalism. Tensions clearly exist between these principles, notably around individual versus collective responsibility and the narrow economic focus of neoliberalism compared to the holistic focus of Mãoridom. But there are also parallels between neoliberal desires to increase choice/competition and reduce the size of government and Māori calls for self-determination, providing the Māori Party with spaces for policy negotiation. In assessing whether the Māori Party achieved its social policy goals, this chapter examines the two key social policy initiatives that the Māori Party named as priorities in relationship accords, considering how well the twin drive towards rangatiratanga and socio-economic parity, as well as the Māori Party's broader kaupapa, was achieved and to what degree these challenged or embedded neoliberalism.

Table 14.1: Māori and neoliberal principles

\begin{tabular}{|l|l|}
\hline Māori & Neoliberal \\
\hline $\begin{array}{l}\text { Mana whenua Defines Māori by the land } \\
\text { occupied by right of ancestral claim and is } \\
\text { essential for Māori wellbeing. }\end{array}$ & $\begin{array}{l}\text { Laissez faire The market is the } \\
\text { fundamental structure for production } \\
\text { and distribution; state intervention } \\
\text { limited to ensuring laws governing } \\
\text { the market are applied equally. }\end{array}$ \\
\hline $\begin{array}{l}\text { Kaitiakitanga Spiritual and cultural guardianship } \\
\text { of the physical world, involving active exercise of } \\
\text { responsibility in a manner beneficial to resources } \\
\text { and the future welfare of the people. }\end{array}$ & $\begin{array}{l}\text { Property rights Individual ownership } \\
\text { rights to the proceeds generated by } \\
\text { property and control over a resource } \\
\text { or good. }\end{array}$ \\
\hline
\end{tabular}




\begin{tabular}{|c|c|}
\hline Māori & Neoliberal \\
\hline $\begin{array}{l}\text { Te reo rangatira The Māori language 'is the } \\
\text { cornerstone of all that is Māori ... [and] is the } \\
\text { medium through which Māori explain the world'. }\end{array}$ & \multirow{2}{*}{$\begin{array}{l}\text { Economic efficiency Targeting } \\
\text { spending cuts and other } \\
\text { interventions reduce government } \\
\text { expenditure; bureaucratic waste and } \\
\text { inefficiency require 'performance } \\
\text { management' and 'actuarial' models } \\
\text { of assessing financial risk. }\end{array}$} \\
\hline $\begin{array}{l}\text { Mana tupuna/whakapapa Defines 'who } \\
\text { we are, from whom we descend, and what } \\
\text { our obligations are to those who come after } \\
\text { us. This is achieved through the recital of } \\
\text { whakapapa' (genealogy). }\end{array}$ & \\
\hline $\begin{array}{l}\text { Rangatiratanga Attributes of a rangatira } \\
\text { (chief or leader), including humility, leadership } \\
\text { by example, generosity, altruism, diplomacy } \\
\text { and knowledge of benefit to the people. }\end{array}$ & $\begin{array}{l}\text { Small government Decisions } \\
\text { should be made at level closest to } \\
\text { those affected to be effective and } \\
\text { not necessarily best provided by } \\
\text { government. }\end{array}$ \\
\hline $\begin{array}{l}\text { Manaakitanga Acknowledging the mana } \\
\text { (prestige or power) of others as having equal } \\
\text { or greater importance than one's own, through } \\
\text { the expression of aroha (love or concern), } \\
\text { hospitality, generosity and mutual respect. }\end{array}$ & \multirow[t]{2}{*}{$\begin{array}{l}\text { Choice and competition Needed to } \\
\text { ensure individual freedom and self- } \\
\text { interest, leading to privatisation of } \\
\text { many previously government-owned } \\
\text { resources and services. }\end{array}$} \\
\hline $\begin{array}{l}\text { Kotahitanga Unity of purpose and direction, } \\
\text { demonstrated through the achievement of } \\
\text { harmony and moving as one and encouraging } \\
\text { all to make a contribution, to have their say and } \\
\text { then, together, to reach a consensus. }\end{array}$ & \\
\hline $\begin{array}{l}\text { Whānaungatanga Underpins the social } \\
\text { organisation of whānau (extended family), hapū } \\
\text { (sub-tribe) and iwi (tribe) and includes rights and } \\
\text { reciprocal obligations consistent with being part } \\
\text { of a collective. }\end{array}$ & \multirow[t]{2}{*}{$\begin{array}{l}\text { Individual responsibility Citizens } \\
\text { framed as responsible for ensuring } \\
\text { their own wellbeing (and for poor } \\
\text { social outcomes). }\end{array}$} \\
\hline $\begin{array}{l}\text { Wairuatanga } \\
\text { Belief that there is a spiritual existence alongside } \\
\text { the physical, affirmed through knowledge and } \\
\text { understanding of Māori ancestors or gods and } \\
\text { necessary for achieving wellness. }\end{array}$ & \\
\hline
\end{tabular}

Source: Quotes from the Māori Party (2013: 2-6), see also Humpage (2015).

\section{Whānau Ora}

Following a Taskforce on Whānau-Centred Initiatives (2010) proposed in the 2008 relationship accord, the Māori Party secured funding for a new Whānau Ora strategy. This provided inclusive services to families in need in a way that empowers them as a whole, rather than focusing separately on individual family members and their problems. Whānau ora is loosely 
translated as 'family wellbeing', but, unlike nuclear family-focused programs implemented elsewhere, whänau refers to multi-generational family groups made up of many households, supported and strengthened by a wider network of relatives. 'Wellbeing' also encompasses the physical, mental, spiritual and cultural health of Māori (Māori Party 2014). In many ways, Whānau Ora 'simply formalised the manner in which many Māori health providers ... have been operating since their inception in the early 1990s' (Boulton et al. 2013: 27), but its national and international significance lies in the acknowledgement that whanau as a collective hold both rights and obligations through broad, interdependent relationships with tribal and other Māori organisations (Māori Party 2013). Whānau Ora also endorsed 'a group capacity for self-determination' that moves beyond the individualised notions of empowerment evident in mainstream policies (Taskforce on Whānau-Centred Initiatives 2010: 30).

As the first Minister for Whānau Ora, Turia led the strategy that was jointly implemented by the Ministry of Māori Development (TPK 2015) and the Ministries of Social Development and Health with multiple government agencies required to work together to assist families. 'Joinedup government' is trending internationally but here is aligned with a Māori world view that social issues are interconnected and must be addressed holistically. The first phase of the strategy involved three initiatives:

- Whānau plans: By 2015, almost two-thirds of whānau engaged with Whānau Ora had been funded to develop plans of action, with most meeting their goals and producing other benefits such as reconnecting whannau members or identifying skills and expertise already within whānau (Auditor-General 2015, TPK 2015). The plans thus supported self-determination at the whannau level; some also preserved whänau histories, cultural traditions and/or traditional lands, or established/ maintained connections to family lands and whänau/tribal groupings (Māori Party 2013).

- Provider collectives and navigators: Funding encouraged providers to form collectives to deliver coordinated services addressing both individuals and whänau needs and to employ 'navigators' who work intensively with 15 or more whänau each year, assisting families to access the varied services offered by government (Auditor-General 2015). By 2014, 32 collectives represented more than 180 independent Māori, Pasifika, health and social services providers as well as tribal organisations (Turia 2014). Navigators had worked with 58 per cent 
of families engaged with Whānau Ora and '[t]hose whānau who were engaged with more services and programmes experienced more improvements' (TPK 2015: 43), resulting in increasing funding in 2014 and 2016 (Auditor-General 2015, English 2016).

- Integrated contracting and government agency support: Improvements in the efficiency of contract management aimed to provide the time available for building provider capability to deliver whänau-centred services (Auditor-General 2015).

The Auditor-General's (2015: 4) report on the first four years of the strategy described Whānau Ora as 'an opportunity for providers of health and social services in the community to operate differently and to support families in deciding their best way forward'. It challenged neoliberal individualism by incorporating a collective focus that acknowledges the negative impact neoliberal reforms have had on Māori families. Te Puni Kōkiri's (TPK 2015) analysis of provider reports and whānau plans suggests that culturally specific whannau plans and the integrated service knowledge of navigators are helping families, with 60-75 per cent reporting improved safety, access to services, happiness, motivation, positive whānau relationships, mutual respect, parenting/caregiving confidence, skills and education/training. Around half of evaluated whänau saw improvements in early education use, healthy housing situation, eating/exercise, cultural confidence and whakapapa knowledge. The latter two items indicate Whānau Ora may facilitate cultural revival, although Boulton and Gifford's (2014: 9) analysis of 46 whänau interviews suggest this is not yet central to everyday Māori understandings of whänau ora.

More fundamentally, requiring whannau to apply for funding via a legal entity responsible for any resulting contract indicates that Whānau Ora, like previous capacity-building initiatives, embedded Māori within Western models of governance (Humpage 2005). Only 34 per cent of provider collectives described government agencies as becoming more responsive to whänau-centred approaches and the Auditor-General (2015:5) noted 'the providers are mainly required by their contracts with government agencies to deliver services to individuals ... The signals currently sent by different parts of government are, at best, mixed'. Dormer's (2014) interviews with government officials and Whānau Ora providers further suggested that the silo mentality associated with neoliberal contractingout processes and performance management models was not overcome. 
Boulton et al. (2013: 28) note:

[e]arlier research with Māori health providers indicates that local or regional difference is rarely reflected in contracts, and that in circumstances where it is, these differences are not translated into performance measures that are meaningful to either the provider or the community they service.

Yet attempts to develop outcome indicators regionally were inconsistent and contributed to a lack of clear, generic outcomes that enabled an assessment of whether the strategy made a significant difference to Māori lives nationally. Most outcome indicators also remained focused on individuals, not whänau collectively (Auditor-General 2015, Boulton et al. 2013). These concerns, along with delays in whänau and providers getting funding and almost a third of total spending going on administration (Auditor-General 2015), saw the National and Māori parties commit to an engagement strategy with whänau, tribal and Māori organisations in 2014 to improve understanding of how policies are impacting on local communities (Bedwell 2014).

But such problems also justify further 'privatisation' of service delivery and responsibility. While the Taskforce (2010) proposed a standalone commissioning agency as the second and final phase of Whānau Ora, enabling greater Māori control over decision-making and governance of the Māori social service sector, three agencies were established: one each for the North and South islands and one for Pasifika peoples across the country. The commissioning agencies sought applications from and entered into contracts for funding from any communitybased organisation in any sector (Auditor-General 2015), using funds transferred from Ministry of Social Development programs aligned with the Whānau Ora approach (Tolley \& Flavell 2016). Although offering greater Māori control over government funding, commissioning agencies also trialled payments-by-results mechanisms that have been widely criticised internationally (see Gustafsson-Wright et al. 2015) and are part of the National Government's experimentation with funding models that are 'a step toward smaller government and a society in which individuals look to themselves and services provided by market-like forces rather than government intervention' (Dormer 2014: 843). This clearly sat in tension with the collective Māori values and aspirations articulated by the strategy and the Mãori Party. 
The strategy's intended focus on Mãori self-determination was also diminished by the shift to include Pasifka peoples, which reflects former prime minister John Key's view that Whānau Ora should be used by all New Zealanders, as well as their similarly poor socio-economic outcomes (Marriott \& Sim 2014). While this inclusive approach arguably reflects the principle of manaakitanga (Dormer 2014), it also means that Māori made up only 64 per cent of the 9,408 whannau comprising 49,625 individuals who had benefited from Whānau Ora by June 2014. TPK's (2015: 90) analysis concluded that '[a] strengths-based approach without an emphasis on rangatiratanga does not generate whānau independence and leadership'. Thus, the whannau focus may be easily translated to other New Zealanders, but this comes at the risk of diminishing the potential to transform state-Māori relationships either through service delivery or the new funding mechanisms.

\section{Ministerial Committee on Poverty}

It is doubtful if Whānau Ora's work to reverse negative social outcomes will be successful long-term unless there are improvements in the disproportionately poor material circumstances many Māori face (Marriott \& Sim 2014). Frustrated by progress in this area, the Mãori Party negotiated a new Ministerial Committee on Poverty in 2011 to bring a greater focus to, and improve co-ordination of, government activity aimed at alleviating the effects of poverty in Aotearoa/New Zealand' (NP \& MP 2011: 2). Co-chaired by the deputy prime minister and Minister of Finance and Turia, the quarterly committee brought together the Ministers of Health, Education, Tertiary Education, Skills and Employment, Social Development, Social Housing, Māori Affairs and Whānau Ora (NP \& MP 2011).

However, alongside reviewing 'the effectiveness of current approaches and responses against a backdrop of Better Public Services and getting value for money for taxpayers', the Committee prioritises the neoliberal view that ' $[\mathrm{w}]$ ork is the primary route out of poverty .... and educational achievement is the platform for creating opportunity' and mobility (Department of Prime Minister and Cabinet 2016). Thus, it frames individuals, rather than structural inequalities, as the 'problem'. The Committee's achievements were also rather ad hoc; although not intended to lead to culturally specific initiatives, those with particular benefit for Māori included: 
- A new free home insulation program: Targeted around 46,000 lowincome households containing children, the elderly and people with pre-existing health conditions by matching government investment with funding from landlords, trusts and other third parties.

- NZ\$21.6 million over four years to expand rheumatic fever prevention beyond school-based programs, as well as the extension of free general practitioner visits and prescriptions to under-13year-olds: Both likely significantly impacted Māori families, who are disproportionately affected by rheumatic fever due to over-crowding, as well as other poverty-related diseases (Leahy 2015, Marriott \& Sim 2014).

- NZ\$790 million hardship fund to increase the incomes of benefit recipients with children by NZ\$25 per week: The was the first core benefit increase since 1972. Fox (2015) estimated that 310,000 families and 570,000 children-including 100,000 Māori families with 89,000 children - would benefit from this and smaller increases for working families from 2016. In return, however, sole parent benefit recipients faced work obligations when their child turns three (up from age five). Focusing only on benefit recipients with children is also less effective in reducing poverty than Māori Party (2008, $2011,2014)$ proposals to increase core benefit levels across the board; introduce a universal child benefit and an official poverty line and target for eliminating child poverty by 2020 ; eliminate tax on the first NZ\$25,000 of income; reintroduce a universal living allowance for tertiary students and abolish tertiary tuition fees; and invest in a model of reciprocal and collective development based on food security. This suggests the hardship fund was a major compromise for the Māori Party.

- New trades training and employment programs: These included targeting rural unemployed youth for employment opportunities on local projects of up to six months paid at minimum wage; 3,000 zerofee Māori and Pasifika trade training placements each year for four years (with plans to double this number to 6,000); and 350 cadetships for unemployed Māori involving at least six months' paid employment and mentoring from employers (Leahy 2015). Such initiatives aimed to better incorporate Māori into the neoliberal labour market and were inadequate, given TPK's (2015) research found 29 per cent of Whānau Ora provider collectives indicated their outcomes were limited by poor employment or education opportunities. Budget 2016 funding 
for a new microfinance program to improve financial independence for whänau-including whänau-led small and medium enterpriseswhile more adequate than other measures, still regarded inclusion in the capitalist economy as the key solution to Mãori poverty (English 2016).

Although not directly associated with the Committee, it is important to acknowledge that a new Māori Housing Strategy and a Māori Housing Network in 2015 both facilitated greater roles for iwi and other Māori organisations in building and managing social housing to better meet Māori needs, while the Māori and Pacific Health Innovation Funds aimed to support communities to find their own health solutions (Flavell 2014, Māori Party 2014). However, like Whānau Ora, these were part of National's broader plans to decentralise and privatise social service provision (Flavell 2014, English 2016).

Such limited gains saw Turia (in Radio New Zealand 2014) criticise government ministers for failing to fully support the Ministerial Committee on Poverty. The Mãori Party negotiated the Committee's continuity and a role on it for non-ministerial Māori Party MP, Marama Fox, in 2014, alongside an agreement that TPK should urgently refocus on strategic policy advice improving Māori employment and training, housing and education outcomes alongside continued work on a Māori Economic Strategy (NP \& MP 2014). But a lack of progress on poverty was a major reason that MP Hone Harawira left the Mãori Party in 2011 to form the Mana Party, which specifically addresses poverty among Māori and non-Māori. This public disharmony not only threatened the principle of kotahitanga - the idea that the Mãori Party works for unity among Māori people, respecting and enhancing the status of all involved — but highlights both the limits of the Māori Party's influence on National and significant overlaps in its neoconservative agendas when it comes to work and welfare (Māori Party 2013). Although incorporation into the Western capitalist economy can benefit Māori (see Bargh this volume, Chapter 16), the collective focus of Whannau Ora was notably absent. Ultimately, it is unlikely the Ministerial Committee on Poverty fundamentally improved the material circumstances of Mãori by offering greater control over their economic lives. Poverty rates among both the whole population and children remained remarkably high and steadywith Māori disproportionately likely to be affected-across the Nationalled government's time in power from 2008 (Perry 2016). 


\section{Conclusion: Success within the boundaries of neoliberalism}

The Māori Party negotiated some significant and innovative social policy initiatives, supporting Smith's (2010: 215) argument that: 'In terms of representation and power, the Mãori Party have achieved more than any other Māori electoral group'. As with any party, it has not been able to implement all of its policy goals, but evidence suggests that Whānau Ora and the Ministerial Committee on Poverty would not exist without the Māori Party's formal relationship with National and the former is showing signs of making a real difference to Māori lives. The first section of Table 14.2 summarises how these initiatives, particularly Whānau Ora, challenged the normalising effects of neoliberalism. The Māori Party also reshaped the state-Māori relationship by rejecting traditional adversarialstyle politics and emphasising manaakitanga or maintaining honest and respectful relationships with all parties, while its consultation with Māori Party members prior to each relationship accord challenges the common criticism that 'consultation' under neoliberalism is an empty promise (Humpage 2005).

Table 14.2: Māori Party policy challenged and extended neoliberalism

\begin{tabular}{|c|c|c|}
\hline & $\begin{array}{l}\text { Whānau } \\
\text { Ora }\end{array}$ & $\begin{array}{l}\text { Ministerial Committee } \\
\text { on Poverty }\end{array}$ \\
\hline \multicolumn{3}{|l|}{ Challenged neoliberalism } \\
\hline Embedded Māori principles in mainstream policy & $\checkmark$ & $x$ \\
\hline Recognised there is not only one cultural 'norm' & $\checkmark$ & $\checkmark$ \\
\hline $\begin{array}{l}\text { Moved away from sole focus on individual } \\
\text { responsibility }\end{array}$ & $\checkmark$ & $\checkmark$ \\
\hline $\begin{array}{l}\text { Attempted to deal with impact of neoliberal } \\
\text { reforms on family functioning/cultural } \\
\text { preservation, etc. }\end{array}$ & $\checkmark$ & $\checkmark$ \\
\hline $\begin{array}{l}\text { Implemented rangatiratanga by recognising the } \\
\text { leadership and authority of iwi, hapū and whānau }\end{array}$ & $\checkmark$ & $x$ \\
\hline $\begin{array}{l}\text { Attempted to move away from 'silo-based' } \\
\text { funding and policymaking }\end{array}$ & $\checkmark$ & $\checkmark$ \\
\hline \multicolumn{3}{|l|}{ Extended neoliberalism } \\
\hline $\begin{array}{l}\text { Extended neoliberal 'contracting out' processes, } \\
\text { embedding Māori organisations further into } \\
\text { a government-funded and led system }\end{array}$ & $\checkmark$ & $\checkmark$ \\
\hline
\end{tabular}




\begin{tabular}{|l|c|c|}
\hline & $\begin{array}{c}\text { Whānau } \\
\text { Ora }\end{array}$ & $\begin{array}{c}\text { Ministerial Committee } \\
\text { on Poverty }\end{array}$ \\
\hline $\begin{array}{l}\text { Embedded Māori into a 'performance } \\
\text { management' model of governance }\end{array}$ & $\checkmark$ & $\checkmark$ \\
\hline $\begin{array}{l}\text { Potentially shifted blame for poor outcomes } \\
\text { onto Māori }\end{array}$ & $\checkmark$ & $\checkmark$ \\
\hline $\begin{array}{l}\text { Embedded Māori into neoliberal labour market/ } \\
\text { economy }\end{array}$ & $\checkmark$ & $\checkmark$ \\
\hline
\end{tabular}

Source: Author's summary.

Nonetheless, manaakitanga arguably constrained the Māori Party from achieving greater success in social policy. Voters might have simply been unaware of Māori Party achievements, since National took much of the credit and the Green and Labour parties often supported (and sometimes claimed as their own) Māori Party initiatives, but electoral resultsparticularly in 2017 when the Māori Party failed to hold even one Māori electorate seat - suggest that Māori voters were critical of the compromises the Māori Party made to maintain a good relationship with National. These include claims (summarised in the second column of Table 14.2) from working-class Māori that the party was beholden to National and driven by tribal elites. This is because it supported a neoliberal agenda through supply and confidence votes, exploited opportunities to win gains for Māori by endorsing policies extending commodification, privatisation and marketisation (Harawira 2011, for alternative views see McCormack and Bargh this volume, Chapters 15 and 16 respectively) and/or potentially devolved responsibility and blame for continued poor outcomes onto Māori. In the 2014 election, when the Māori Party held only one Māori electorate and had only two MPs in parliament (Bargh 2015), Flavell (cited by Bedwell 2014) reported consultations where '[o] ur people said it's vital for the Māori Party to be in Government so we can help reset the current landscape and deliver more tangible gains for Māori'. But 2017 demonstrated that most Māori are not voting for the Māori Party or its candidates. Notably, however, this was not the result of National broadening its political base, as it had hoped, because Labour won all seven Māori electorates (Election Aotearoa 2017).

The Mãori Party's achievements indicate that supply and confidence relationships can bring important, incremental gains-including internationally significant policies that embed indigenous cultural values and governance within mainstream social policy frameworks-benefiting indigenous peoples. But such relationships also require compromises 
that further embed neoliberalism. By tying them to indigenous agendas and politics, it is possible that this may also make it less likely that some indigenous peoples will challenge neoliberal principles and policies in the future. This does not bode well for greater recognition of indigenous/ Treaty rights and the material disadvantage faced by Māori. Although many Māori voted for the Labour and New Zealand First parties who, in 2017, claimed that neoliberalism had 'failed' (Election Aotearoa 2017), it remains uncertain as to whether they together will represent a significant challenge to the neoliberalism agendas that detrimentally impact many Māori New Zealanders or if they will extend or constrain the innovative social policies initiated by the Māori Party.

\section{References}

Auditor-General (2015). Whannau Ora: The first four years, Office of the AuditorGeneral, Wellington.

Bargh M (2015). The Māori seats. In Hayward J (ed.), New Zealand government and politics, 6th edition, Oxford, Melbourne.

Bedwell Q (2014). Agreement between the Mãori Party and National Party welcomed, www.maoriparty.org/agreement_the_Maori_party_and_national.

Boulton A \& Gifford H (2014). Whānau Ora; He whakaaro ā whānau: Māori family views of family wellbeing. The International Indigenous Policy Journal 5(1):1-16, doi.org/10.18584/iipj.2014.5.1.1.

Boulton A, Tamehana J \& Brannelly T (2013). Whānau-centred health and social service delivery in New Zealand: The challenges to, and opportunities for, innovation. MAI Journal 2(1):18-32.

Clarke J (2004). Dissolving the public realm: The logics and limits of neoliberalism. Journal of Social Policy 33(1):27-48, doi.org/10.1017/S0047279403007244.

Department of Prime Minister and Cabinet (2016). Ministerial Committee on Poverty, www.dpmc.govt.nz/dpmc/publications/mcop.

Dormer D (2014). Whānau Ora and the collaborative turn. International Journal of Public Administration 37(12):835-45, doi.org/10.1080/01900692.2014. 917101.

Election Aotearoa (2017). Election Aotearoa, www.maoritelevision.com/election. 
English B (2016). Summary of initiatives in Budget 2016, www.treasury.govt.nz/ budget/2016/summary-initiatives/b16-sum-initiatives.pdf.

Flavell TU (2014). Last speech in the 50th Parliament, Scoop, 31 July, www. scoop.co.nz/stories/PA1408/S00006/maori-party-last-speech-in-the-50thparliament.htm.

Fox M (2015). Māori Party delivers for vulnerable whānau. Scoop, 21 May, www. scoop.co.nz/stories/PA1505/S00361/maori-party-delivers-for-vulnerablewhanau.htm.

Gustafsson-Wright E, Gardiner S \& Putcha V (2015). The potential and limitations of impact bonds: Lessons from the first five years of experience worldwide, Brookings Institution, Washington DC.

Harawira H (2011). Hone Harawira's statement on his caucus suspension, New Zealand Herald, 8 February, www.nzherald.co.nz/nz/news/article. cfm?c_id=18xobjectid=10704905.

Humpage L (2005). Experimenting with a 'whole of government' approach: Indigenous capacity building in New Zealand and Australia. Policy Studies 26(1):47-66, doi.org/10.1080/01442870500041744.

Humpage L (2015). Policy change, public attitudes and social citizenship: Does neoliberalism matter? The Policy Press, Bristol.

Leahy H (2015). Crossing the floor, Huia, Wellington.

Māori Party (2008). Policy priorities: He aha te mea nui? - he tangata, Māori Party, Wellington.

Māori Party (2011). Our whānau: Our future, Māori Party, Wellington.

Māori Party (2013). Māori Party constitution, Māori Party, Wellington.

Māori Party (2014). Māori Party policy manifesto, Māori Party, Wellington.

Marriott L \& Sim D (2014). Indicators of inequality for Māori and Pacific people. Business school working paper in public finance 09/2014, Victoria University of Wellington, Wellington.

NP \& MP (National Party \& Māori Party) (2008). Relationship and confidence and supply agreement between the National Party and the Mãori Party, National Party \& Māori Party Wellington.

NP \& MP (2011). Relationship accord and confidence and supply agreement with the Māori Party, National Party \& Māori Party, Wellington. 
NP \& MP (2014). Relationship accord and confidence and supply agreement with the Mãori Party, National Party \& Māori Party, Wellington.

Peck J \& Tickell A (2002). Neoliberalizing space. Antipode 34(3):380-404, doi. org/10.1111/1467-8330.00247.

Perry B (2016). Household incomes in New Zealand: Trends in indicators of inequality and hardship 1982 to 2015, Ministry of Social Development, Wellington.

Radio New Zealand (2014). Poverty committee not fully supported-Turia, 20 April, www.radionz.co.nz/news/political/242116/poverty-committee-notfully-supported-turia.

Sachdeva S (2015). Maori Party: Quiet achievers want to raise profile in 2016, Stuff.co.nz, 8 December, www.stuff.co.nz/national/politics/75133560/MaoriParty-Quiet-achievers-want-to-raise-profile-in-2016.

Smith K (2010). Māori political parties. In Mulholland M and Tawhai V (eds), Weeping waters: The Treaty of Waitangi and constitutional change, Huia, Wellington.

Sykes A (2010). The politics of the brown table. Scoop, 19 October, www.scoop. co.nz/stories/PO1010/S00199/the-politics-of-the-brown-table.htm.

Taskforce on Whānau-Centred Initiatives (2010). Whānau Ora: Report of the Taskforce on Whānau-Centred Initiatives, Ministry of Social Development, Wellington.

Tolley A \& Flavell TU (2016). Funding and programmes for whänau-centred services transferred to Whanau Ora, media release, www.beehive.govt.nz/release/ funding-and-programmes-wh\%C $4 \% 81$ nau-centred-services-transferredwh\%C $4 \% 81$ nau-ora.

TPK (Te Puni Kōkiri) (2015). Understanding whānau-centred approaches: Analysis of Phase One Whānau Ora research and monitoring results, Te Puni Kōkiri, Wellington.

Turia T (2006). Speech to ACT National Conference, Scoop, 27 March, www.scoop.co.nz/stories/PA0603/S00443/turia-speech-to-act-nationalconference.htm.

Turia T (2014). Whānau Ora achievements report July 2014, Office of the Minister Responsible for Whānau Ora, Wellington. 
This text is taken from The Neoliberal State, Recognition and Indigenous Rights: New paternalism to new imaginings, edited by Deirdre Howard-Wagner, Maria Bargh and Isabel AltamiranoJiménez, published 2018 by ANU Press, The Australian National University, Canberra, Australia.

doi.org/10.22459/CAEPR40.07.2018.14 